\title{
al-Balagh \\ Jurnal Dakwah dan Komunikasi
}

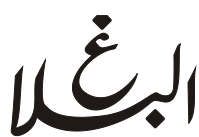

http://ejournal.iain-surakarta.ac.id/index.php/al-balagh

\section{HAJINYA LANSIA DITINJAU DARI PERSPEKTIF BIMBINGAN DAN KONSELING ISLAM}

\section{Kholilurrohman \\ IAIN Surakarta}

\begin{tabular}{|c|c|}
\hline & Abstract \\
\hline Keywords: & Hajj is the fifth pillar of Islam. When the first pillar of Islam until \\
\hline $\begin{array}{l}\text { Hajj, Islamic } \\
\text { Guidance and } \\
\text { Counseling }\end{array}$ & $\begin{array}{l}\text { the fourth has been done, the Muslims wants to complete the pillar } \\
\text { by performing the pilgrimage as the fifth obligation. However, } \\
\text { in modern times today, along with the increasing number of hajj } \\
\text { quotas, automatically caused the turn period of hajj to be increased } \\
\text { as well. In fact, it raises some problems, especially for the elder }\end{array}$ \\
\hline & $\begin{array}{l}\text { Hajj pilgrims. This research aims to identify some problems that } \\
\text { arise from the preparation of Hajj until the completion of Hajj } \\
\text { in the elderly congregation. The problem is studied based on the } \\
\text { perspective of Islamic guidance and counseling by using literature } \\
\text { review. This research also uses qualitative approach in the form of } \\
\text { case study technique. The result, there are some problems of Hajj } \\
\text { experienced by the elderly so that it's needful for assistance and } \\
\text { psychological guidance in the implementation of the pilgrimage by } \\
\text { the elderly congregation. }\end{array}$ \\
\hline
\end{tabular}

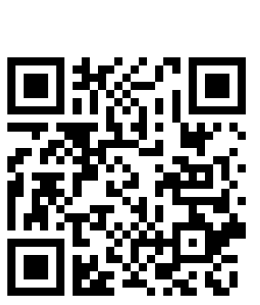

DOI Number

$10.22515 /$ balagh.v2i2.1021

\section{Abstrak}

Ibadah haji merupakan rukun Islam yang kelima. Ketika rukun Islam yang pertama sampai yang keempat sudah terlaksana, umat Islam ingin menyempurnakan dengan menunaikan ibadah haji sebagai kewajiban yang kelima. Namun demikian, di zaman modern saat ini, seiring dengan semakin bertambahnya kuota haji, pada akhirnya menyebabkan masa tunggu giliran haji menjadi bertambah pula. Hal ini nyatanya memunculkan beberapa permasalahan, terutama bagi para calon jamaah haji yang lanjut usia. Penelitian ini bertujuan untuk 
Kata Kunci:

Haji, Bimbingan dan Konseling Islam mengidentifikasi beberapa permasalahan yang muncul sejak persiapan haji sampai selesainya haji pada jamaah lanjut usia. Permasalahan tersebut dikaji berdasarkan perspektif bimbingan dan konseling Islam dengan menggunakan kajian literatur. Penelitian ini juga menggunakan pendekatan kualitatif dengan teknik studi kasus. Hasilnya, terdapat beberapa permasalahan haji yang dialami oleh para lanjut usia sehingga diperlukan adanya pendampingan dan bimbingan psikologis dalam pelaksanaan ibadah haji oleh para jamaah lanjut usia.

\section{PENDAHULUAN}

Haji merupakan rukun Islam yang kelima. Ketika seseorang sudah berhasil menunaikan keempat rukun Islam sebelum haji (syahadat, shalat, puasa, dan zakat), maka seseorang terdorong untuk menunaikan haji. Dalam Islam, penekanan haji tidak sekuat penekanan syahadat, shalat, puasa, dan zakat. Dengan kata lain, ibadah haji memiliki dua status hukum, wajib bagi yang mampu dan tidak wajib bagi yang tidak mampu. Kesimpulan ini didapatkan dari Al Qur’an Surat Âli 'Imrân ayat 97: “mengerjakan haji adalah kewajiban manusia terhadap Allah, yaitu (bagi) orang yang mampu mengadakan perjalanan ke Baitullab". Mampu dalam ayat ini memiliki makna mampu secara keilmuan, finansial, fisik, psikis, dan keamanan dalam perjalanan.

Tingginya minat masyarakat untuk menunaikan ibadah haji juga kemudian membuat antrian dalam melaksanakan haji dalam suatu negara semakin banyak. Berbagai karakteristik masyarakat, mulai dari yang berusia muda sampai berusia tua dan lanjut usia, menginginkan untuk bisa menjalankan ibadah haji. Tulisan ini akan memfokuskan pembahasan mengenai ibadah haji yang dilaksanakan lanjut usia. Mengingat ibadah haji adalah wajib bagi yang mampu (salah satunya mampu secara fisik dan psikis) sedangkan kemampuan fisik dan psikis lanjut usia cenderung menurun. Terlebih jika lanjut usia tersebut memiliki beberapa penyakit dan rentan terhadap penyakit. Karena seseorang yang menginjak usia lansia umumnya sudah memiliki penyakit, seperti kolesterol, asam urat, darah tinggi, vertigo, gagal ginjal, diabetes, dan penyakit lainnya. Kondisi ini menjadi dilema tersendiri, baik bagi lansia sendiri maupun bagi penyelenggara haji atau pemerintah. 
Berbicara ibadah haji, bukan hanya berbicara mengenai pelaksanaan haji itu saja. Ibadah haji sendiri dilaksanakan kurang lebih selama 40 hari (dalam konteks Indonesia). Tidak hanya itu, terdapat ritual budaya yang menyertai sebelum keberangkatan haji, seperti: empat bulan mengikuti bimbingan manasik haji setiap hari Minggu, silaturrahim sesama regu karena pamitan, penyelenggaraan pamitan di rumah sendiri, melayani tamu dari sanak saudara dan handai taulan, serta latihan jalan kaki setiap pagi untuk pembelajaran fisik karena rangkaian ibadah haji di Mekkah dan Madinah mengandalkan jalan kaki. Rangkaian kegiatan ini tentu saja melelahkan, terutama bagi lanjut usia.

Persoalan haji bagi lanjut usia bertambah ketika peminat haji setiap tahun meningkat sehingga menyebabkan waktu tunggu semakin lama. Saat ini, jangka waktu sejak pendaftaran sampai menunaikan ibadah haji minimal 10 tahun. Artinya, ketika seseorang mendaftar haji di usia 50 tahun ditambah waiting list 10 tahun, maka seseorang diperkirakan akan berangkat di usia 60 tahun. Usia 60 tahun ini rentan dengan penyakit atau minimal kemampuan fisik sudah melemah.

Belum lagi terkait dengan fenomena kematian jamaah haji. Bagi pemerintah, wajib menjaga keselamatan jamaah haji sejak keberangkatannya sampai kepulangannya. Atas dasar ini, maka pemerintah memberikan fasilitas kesehatan di setiap kloter. Fasilitas kesehatan tersebut misalkan dokter dan para perawat. Salah satu ikhtiar untuk menjaga keselamatan ini misalkan menjaga pola makan, olah raga, dan sikap hidup sehat. Di sisi lain, keluarga yang memiliki anggota keluarga lansia yang mengikuti ibadah haji, secara mental sudah siap untuk segala kemungkinan, dan kemungkinan terburuk ketika menunaikan ibadah haji adalah kematian.

Menurut ilmu fiqh, manasik haji ada tiga komponen, yakni: rukun, wajib, dan sunnah. Termasuk komponen rukun haji, yakni; (1) niat ihbrâm; (2) memakai ibrâm; (3) wukuf di 'Arafah; (4) thawaf ifadhah; dan (5) sa'i. Termasuk komponen wajib haji, yakni: (1) mabit di Muzdalifah; (2) melempar jumrah; (3) mabit di Mina; dan (4) thawaf wada'. Dan termasuk sunnah haji, yakni: (1) mandi; (2) memotong kuku; (3) memotong/merapikan rambut; 
(4) memakai wewangian di tubuh; (5) shalat sunnah ihrâm; (6) doa memakai pakaian ihrâm; (7) doa di Multazam/searah Multazam; (8) shalat sunnah di belakang maqam Ibrahim; (9) shalat sunnah di bijr Ismail, dll.

Maka sebenarnya bila seseorang melakukan tahapan-tahapan haji dan umrah sesuai yang disyariatkan (figh) Insya Allah tidak ada masalah/tidak ada kesulitan. Misalnya, karena jamaah haji Indonesia mengambil model haji tamattu', tahapannya adalah umrah terlebih dahulu, dan dilanjutkan haji. Adapun rangkaian umrah yakni: (1) mandi sunnah ibrâm; (2) memakai pakaian ibrâm; (3) memakai wewangian di badan; (4) merapikan rambut/

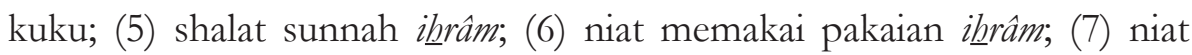
umrah dan ihbram-nya di miqat, (9) thawaf, (10) sa'i; (11) tạallul; dan (12) tertib.

Sedangkan untuk tahapan-tahapan manasik haji; (1) mandi sunnah ibrâm; (2) memakai pakaian ihbrâm; (3) memakai wewangian di badan; (4)

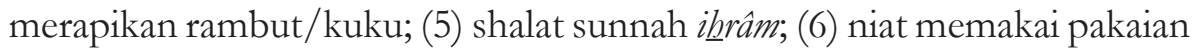
ihrâm; (7) niat haji dan ihbram-nya di miqat; (8) wukuf di 'Arafah; (9) mabit di Muzdalifah; (10) mencari kerikil; (11) melempar jumrah 'aqabah; (12) mabit di Mina; (13) melempar jumrah ula, wustha, 'aqabah pada tanggal 11, 12, dan 13 Dzulhijjah; (14) thawaf ifadhah; dan (15) sa'i. Ketika akan meninggalkan Makkah, masih ada thawaf lagi, yakni: thawaf wada'.

Berdasarkan penjabaran mengenai rangkaian ibadah haji dan segala resiko yang mungkin terjadi, maka penting untuk menggali dinamika ibadah haji yang dilakukan oleh lansia. Hal ini penting untuk merumuskan mengenai model bimbingan dan konseling guna memudahkan pelaksanaan ibadah haji lansia.

\section{METODE PENELITIAN}

Penelitian ini menggunakan pendekatan kualitatif dengan teknik atau metode studi kasus. Penelitian ini mengambil pengalaman subjek yang berusia lanjut usia (usia mulai 60 tahun) selama rentang waktu sejak tahun 2012 sampai 2017. Subjek yang diteliti adalah lanjut usia yang melaksanakan ibadah haji dan berasal dari Klaten, Jawa Tengah, Indonesia. 
Penulis selain berperan sebagai peneliti, juga memiliki peran sebagai Tim Petugas Pendamping Ibadah Haji (TPIHI) selama rentang waktu tersebut.

\section{HASIL PENELITIAN}

Terdapat beberapa hasil penelitian yang penting untuk dibahas dalam jurnal ini. Pertama, mengenai kesehatan jamaah haji lansia. Para jamaah haji lansia sudah mulai menderita beberapa penyakit, seperti kolesterol, asam urat, asma, vertigo, diabetes, dan sebagainya. Penyakitpenyakit ini bisa mempengaruhi kondisi dan ketahanan fisik jamaah haji lansia sehingga fisik jamaah haji mudah mengalami kelelahan.

Selain mengalami gangguan kesehatan fisik, jamaah haji lansia juga mengalami gangguan psikis. Misalkan, ingin segera pulang ke tanah air akan tetapi rangkaian ibadah haji belum selesai. Selain itu, jamaah haji Indonesia yang lansia mudah mengalami ketersesatan jalan pulang menuju ke hotel.

Kedua, keilmuan jamaah haji. Tidak setiap jamaah haji paham secara mendalam mengenai rangkaian ibadah haji. Terutama para jamaah lansia yang mengalami penurunan daya kognisi dan membuatnya sulit untuk belajar. Misalnya, meskipun sudah diberikan materi bahwa seseorang harus suci dari hadas kecil dan besar ketika melaksanakan thawaf, faktanya masih ada jamaah haji lansia yang tetap melaksanakan thawaf walau berhadas kecil (misalkan kentut). Sebenarnya, jamaah haji paham bahwa kentut dapat membatalkan thawaf. Akan tetapi, banyak faktor yang mendorong jamaah haji untuk tidak berwudlu kembali, misalkan takut tertinggal oleh rombongan.

Ketiga, mental internasional. Tidak dapat dipungkiri bahwa jamaah haji Indonesia rata-rata belum pernah pergi ke luar negeri. Apalagi naik pesawat terbang yang lamanya sekitar $12 \mathrm{jam}$. Tentu sebuah pengalaman yang sangat berbeda. Ini menjadi persoalan serius terkait tekanan udara di luar pesawat yang berakibat pada kepala pening, sesak nafas, menahan buang air kecil, dan mabuk ketinggian. 
Berbagai permasalahan tersebut, sudah seharusnya dicarikan formula untuk membimbing jamaah haji lansia. Tentu saja bukan hanya bimbingan secara agama saja, tetapi juga bimbingan secara psikis. Karena untuk memahami jamaah haji lansia, diperlukan banyak konsep bimbingan dan konseling serta psikologi.

\section{PEMBAHASAN}

Berbagai fenomena dan permasalahan haji lansia tersebut dapat dikaji dengan perpektif psikologi, khususnya psikologi humanistik. Gobel (1992) menganggap bahwa madzhab psikologi humanistik tersebut menjadi madzhab ketiga setelah paradigma psikodinamika dan behavioral. Beberapa tokoh madzhab psikologi humanistik adalah Abraham Maslow dengan teori motivasi dan aktualisasi diri. Maslow menginginkan psikologi humanistik menjadi madzhab psikologi yang menangani cita-cita dan potensi-potensi yang paling baik dan paling mulia yang sanggup dicapai oleh manusia (Schultz, 1991).

Maslow memiliki beberapa asumsi terkait motivasi. Pertama, Maslow mengadopsi pendekatan sebuah pendekatan yang komprehensif tentang motivasi. Artinya, keseluruhan dari seseorang, bukan bagian atau fungsi. Kedua, motivasi bersifat kompleks yang bermakna bahwa tingkah laku manusia dapat muncul dari beberapa motivasi dalam diri. Ketiga, manusia berulang kali termotivasi oleh kebutuhan-kebutuhannya. Selanjutnya, Maslow menjelaskan bahwa manusia, siapapun itu dan dimanapun berada, termotivasi oleh kebutuhan dasar yang sama. Kebutuhan-kebutuhan tersebut dapat dibentuk menjadi sebuah hierarki (Feist, Feist, \& Roberts, 2017). Artinya, manusia harus memenuhi kebutuhan dasarnya terlebih dahulu sebelum kemudian dapat memenuhi kebutuhan selanjutnya.

Konsep hierarki kebutuhan menjelaskan bahwa manusia memiliki lima kebutuhan yang dapat dipenuhi selangkah demi selangkah. Pertama, kebutuhan fisiologis, termasuk makanan, minuman, oksigen, karena halhal ini yang membuat manusia bertahan hidup dan memiliki tenaga. Hal ini bisa dilihat di beberapa daerah yang mengalami krisis kelaparan, maka 
masyarakatnya hanya berorientasi pada pemenuhan kebutuhan fisiologis berupa makanan. Kedua, kebutuhan akan rasa aman, meliputi keamanan fisik, stabilitas, perlindungan, dan kebebasan dari kekuatan-kekuatan yang mengancam, seperti perang, terorisme, penyakit, rasa takut, kecemasan, bahaya, kerusuhan, dan bencana alam. Sebagian orang bisa jadi tercukupi, sedangkan sebagian orang tidak bisa memenuhi kebutuhan ini, misalkan di daerah rawan bencana dan daerah konflik. Ketiga, kebutuhan akan cinta dan keberadaan, berwujud keinginan untuk berteman, memiliki pasangan dan anak, serta menjadi bagian dari masyarakat dan negara. Kebutuhan ini bisa dipenuhi dan diajarkan manusia sejak kecil. Keempat, kebutuhan akan penghargaan, mencakup penghormatan diri, kepercayaan diri, kemampuan, dan pengetahuan yang dihargai. Pengejawantahan dari kebutuhan ini adalah reputasi dan harga diri. Kelima, kebutuhan akan aktualisasi diri, meliputi kesadaran akan semua potensi diri dan kemudian mengerahkannya untuk mencapai cita-citanya. Menurut Maslow, manusia yang bisa mencapai aktualisasi diri menjadi manusia seutuhnya (Feist, Feist, \& Roberts, 2017; Schultz, 1991; Nasrul, 2010).

Menunaikan ibadah haji merupakan salah satu fenomena yang terkait dengan aktualisasi diri. Jika menakar ibadah haji, ibadah haji merupakan rukun Islam terakhir. Haji merupakan ibadah dan rukun Islam yang paling memerlukan segala potensi, mulai dari daya kognisi, energi fisik, ketahanan psikologis, sampai materi. Berbeda dengan rukun Islam yang lain seperti syahadat, shalat, puasa, dan zakat. Pada titik ini, ibadah haji dapat menjadi sarana aktualisasi diri seseorang. Di sisi lain, ibadah haji ditempatkan sebagai rukun Islam yang terakhir sebagai puncak beragama Islam, diharapkan agar para pemeluk agama Islam dapat menyempurnakan rukun Islam berupa syahadat, shalat, puasa, dan zakat terlebih dahulu sebelum menunaikan haji.

Haji menjadi status sosial dalam masyarakat Indonesia. Hal ini dikarenakan sepulang haji, seseorang akan menambahkan "gelar haji" di depan namanya. Masyarakat pun juga memanggil orang yang sudah menunaikan ibadah haji dengan panggilan "haji", misalkan pak haji 
dan bu haji. Selain itu, menunaikan ibadah haji dianggap menjadi status kehormatan karena ibadah haji memerlukan banyak biaya dan perjuangan.

Kuatnya dorongan untuk aktualisasi diri ini juga menyebabkan jamaah haji tidak mengalami kecemasan kematian. Tidak bisa dipungkiri bahwa ibadah haji memiliki resiko kematian cukup tinggi, terutama bagi lansia. Hal ini dikarenakan ibadah haji dilakukan serentak oleh kaum muslimin sedunia dan berdesak-desakan. Sehingga, jamaah haji rentan jatuh dan terinjak-injak, terutama jamaah haji lansia.

Kematian pun tidak menjadi persoalan dan halangan bagi jamaah haji lansia dan keluarga. Bahkan ada dorongan bahwa jamaah haji yang meninggal saat menjalankan ibadah haji dinilai sebagai busnul khâtimah. Tidak hanya itu, jamaah haji yang wafat dan kemudian dimakamkan di baramain, dijamin tidak ditemui Dajjal ketika hari kiamat sehingga terhindar dari fitnah Dajjal.

Dalam membimbing ibadah haji para lansia, juga dibutuhkan pemahaman karakteristik lansia. Dalam kajian psikologi serta bimbingan dan konseling, terdapat teori psikososial yang disampaikan oleh Erik H. Erikson. Konsep ini menjelaskan tentang perkembangan psikososial individu mulai dari anak-anak sampai lanjut usia. Tahapan perkembangan psikososial ini dituliskan dalam bukunya yang berjudul Childhood and Society. Adapun tahapan perkembangan psikososial tersebut sebagai berikut (Erikson, 1993):

Tabel 1. Tabel Tahapan Psikososial oleh Erikson

\begin{tabular}{llllll}
\hline No & Tahap & Masalah & & & Keutamaan \\
\hline 1 & Oral & Percaya & vs & Tidak percaya & Harapan \\
\hline 2 & Anal & Otonomi & vs & Malu \& rasa bersalah & Kekuatan \& kehendak \\
\hline 3 & Genital & Inisiatif & vs & Rasa bersalah & Tujuan \\
\hline 4 & Latensi & Usaha & vs & Rasa rendah diri & Kemampuan \\
\hline 5 & Remaja & Identitas & vs & Kekacauan peran & Kesetiaan \\
\hline 6 & Pemuda & Intimasi & vs & Isolasi & Cinta \\
\hline 7 & Dewasa & Generativitas & vs & Stagnansi & Perhatian \\
\hline 8 & Lanjut Usia & Integrasi Diri & vs & Putus asa & Kebijaksanaan \\
\hline
\end{tabular}


Berdasarkan tahapan tersebut, lansia rentan mengalami krisis keputusasaan. Krisis ini terjadi karena mayoritas lansia sudah berhenti bekerja sehingga kehilangan makna atas dirinya sendiri. Kehilangan makna ini kemudian bisa menyebabkan keputusasaan. Dalam konteks agama Islam, khususnya rukun Islam, krisis keputusasaan ini sebenarnya bisa diatasi jika lansia melaksanakan ibadah haji. Dengan kata lain, ketika lansia menunaikan ibadah haji, maka lingkungan sosial harus mendukungnya dengan segala upaya antisipasi agar meminimalisir resiko yang terjadi pada lansia selama ibadah haji. Dengan demikian, lansia tidak mengalami krisis keputusasaan.

Upaya dukungan ini bisa dilakukan dengan prinsip unconditional positive regard. Unconditional positive regard ini dipopulerkan oleh Carl Rogers, seorang psikolog humanistik eksistensial. Unconditional positive regard ini adalah penghargaan positif tanpa syarat (Feist, Feist, \& Roberts, 2017; Schultz, 1991; Hall \& Lindzey, 2006). Dalam ranah bimbingan dan konseling, prinsip ini penting untuk menumbuhkan dan memperkuat motivasi seseorang untuk melakukan sesuatu. Selain itu, prinsip ini bisa digunakan dalam konteks membimbing ibadah haji lansia. Di satu sisi, lansia yang rentan akan penyakit tetap dihargai dan tidak dihalangi untuk beribadah haji. Di sisi lain, lingkungan dalam memberikan penghargaan dan dukungan tanpa syarat juga harus memunculkan kesadaran bagi jamaah haji lansia (dan juga lingkungan sendiri) untuk melakukan langkah antisipasi guna meminimalisir resiko ibadah haji. Penghargaan positif tanpa syarat bagi lansia ini juga bertujuan untuk meminimalisir kecemasan dan tekanan serta gangguan psikologis lain yang mungkin terjadi selama ibadah haji. Pada akhirnya, ketika jamaah haji lansia tidak mengalami kecemasan dan tekanan, maka akan mudah untuk melaksanakan ibadah haji.

\section{KESIMPULAN}

Berdasarkan pembahasan tersebut, muncul beberapa kesimpulan. Pertama, dengan segala karakteristik fisik dan psikis lansia, ibadah haji 
lansia rentan akan gangguan fisik dan psikis. Gangguan fisik dan psikis ini bisa menyebabkan ketidaklancaran ibadah haji lansia tersebut. Bukan hanya itu, gangguan fisik dan psikis lansia selama melakukan ibadah haji, juga seringkali berdampak pada kelompok ibadah haji atau pendamping ibadah haji. Maka dari itu, diperlukan formula pendampingan dengan berlandaskan pada konsep dan perspektif bimbingan dan konseling Islam.

Kedua, pendampingan ibadah haji lansia berdasarkan konsep bimbingan dan konseling Islam bisa menggunakan konsep dan teori yang disampaikan oleh Carl Rogers, yaitu penghargaan positif tanpa syarat. Untuk dapat mendampingi dengan penghargaan positif tanpa syarat, maka diperlukan upaya memahami karakteristik psikis lansia. Upaya memahami ini bisa menggunakan perspektif dan teori aktualisasi diri yang disampaikan oleh Abraham Maslow dan teori psikososial yang disampaikan oleh Erik H. Erikson.

Saran. Dengan demikian, formula pendampingan tersebut bisa menjadi saran bagi beberapa pihak yang terkait dengan pelaksanaan ibadah haji. Seperti Kementerian Agama Republik Indonesia, pendamping haji, keluarga lansia yang melaksanakan ibadah haji, dan juga lansia yang melaksanakan ibadah haji itu sendiri.

\section{DAFTAR PUSTAKA}

Erikson, E. H. (1993). Childhood and Society. New York: W.W. Norton \& Company.

Feist, J., Feist, G. J., \& Roberts, T.A. (2017). Teori Kepribadian, Buku 1 Edisi 8 (Terj. R.A. Hadwitia Dewi Pertiwi). Jakarta: Salemba Humanika.

Gobel, F. G. (1992). Maďhab Ketiga. Yogyakarta: Penerbit Kanisius.

Hall, C. S., \& Lindzey, G. (2006). Teori-Teori Holistik (Organismik Fenomenologis), Terj. Dr. A. Supratiknya. Yogyakarta: Penerbit Kanisius.

Nasrul, E. (2010). Pengalaman Puncak. Abraham Maslow. Ponorogo: CIOS Institut Studi Islam Darussalam Pondok Modern Darussalam Gontor. 
al-Balagh - Vol. 2, No. 2, Juli-Desember 2017 | 241

Schultz, D. (1991). Psikologi Pertumbuhan: Model-Model Kepribadian Sehat (Terj. Drs. Yustinus, M.Sc). Yogyakarta: Penerbit Kanisius. 